\title{
PLANT RESOURCE AND UTILIZATION: A CASE STUDY IN KANCHANPUR DISTRICT, FAR-WESTERN TARAI, NEPAL
}

\author{
Gunanand Pant and Ram Kailash P. Yadav* \\ Aishwarya Multiple Campus, Dhangadhi, Kailali, Nepal \\ *Central Department of Botany, Tribhuvan University, Kirtipur, Kathmandu, Nepal \\ Email: gd_pant2000@yahoo.com
}

\begin{abstract}
The present study aims to explore and document the plant resources used by different communities of Suda and Daijee VDC of Kanchanpur district. A total of 151 plant species belonging to 58 families and 133 genera have been identified and documented. Most of them have medicinal properties in their bark, root, and fruits. A large number of these identified species are used for gastro-intestinal problems, rheumatism, chest infection, cut and wound and in fever. Elderly people and traditional healers of the areas have vast knowledge on ethanomedicinal practices along with various rituals in comparison to the young generation. The knowledge transformation system is quite restricted within family. Mostly exploited plant species like Piper longum, Emblica officinalis, Asparagus racemosus, Terminallia chebula, Terminalia bellirica, Acorus calamus, Azadirchta indica, Cordia vestita, Rauvolfia serpentina, Acacia catechu, Cinnamomum tamala, Zinziber officinalis, and Pterocarpus marsupium are under threat of extinction due to growing human pressure as well as habitat degradation impacted by anthropogenic activities such as grazing, expansion of agriculture land, forest fire, etc.
\end{abstract}

Key words: Medicinal plants, community forest, ethnomedicine, Kanchanpur district, far-western Nepal.

\section{INTRODUCTION}

Traditional use of plants for different purposes has a long history in Nepal. The ethnic communities have remarkable customary knowledge on utilization of plant and plant parts and there is a long tradition of transferring this indigenous knowledge from generation to generation. The indigenous knowledge on traditional use of plants is gaining recognition worldwide. In Nepal, Nepal Biodiversity Strategy has also highlighted its importance for proper conservation of Himalayan Biodiversity (NBS
2002). The plant resources for various uses are collected from various habitats. At present, most of these habitats with useful species are under threat due to habitat destruction, unsustainable harvesting and over-exploitation; and many species are already threatened from collection pressure (Ghimire et al. 2005). So, priority should be given to documentation of indigenous knowledge on traditional use and conservation of existing species and habitats before some of these are eliminated from the area (Joshi et al. 2003). 
The Himalayan region harbors about 12,000 species of medicinal and aromatic plants, supporting the livelihood of about 600 million people living in the area (Shengji 2001). Nepal's rich biodiversity can be accounted for its unique geographical position as well as altitudinal and climatic variation. The country comprises over 7000 species of higher plant. Species diversity in Nepal can be well known from the fact that over 1,500 species of medicinal plants have been discovered and described among which more than 300 species are endemic to the country. The list of the Nepalese medicinal plants exceeds over $20 \%$ of the known vascular plant species of the country (Manandhar and Aase 2003). Thirty percent medicinal plant species occurs in the western part of the country (Manandhar 1998) and about 50\% of the plants used as ethnomedicine in Nepal Himalaya have been documented (Kunwar et al. 2008). The people living in rural area generally depend on plants and its products in a traditional way to fulfill the basic requirements for continuing their daily life. They obtain food, fodder, fuel wood, timber, building materials and medicines from plants (Yadav 1999, Shrish et al. 2011a,b).

Moreover, there is outstanding assemblage of cultural and anthropological diversity in the country with more than 60 ethnic societies and more than 75 language groups (Shrestha 1997). The ethnic people residing in different geographical belts of Nepal depend on wild plants to meet their basic requirements and all the ethnic communities have their own pool of secret ethnomedicinal and ethnopharmacological knowledge about the plants available in their surroundings which has been serving rural people with its superiority. Particularly, the medicinal and aromatic plants are flourished well in the virgin Himalaya as well as in damp tropical forests, many of which are still awaiting to disclose their many secrets. Unfortunately large number of wild plants are at the verge of disappearance due to over exploitation and ecological disturbances but detail information about their economic potential are yet not fully recorded. Furthermore, the practice and dependence of aboriginal on these resources is rapidly declining owing to changing life style, reluctance of elderly people on passing the secret on their use and negligence of youngsters. Therefore, the knowledge of utilization of the resources is of great importance and it can be promoted by considering and documenting the diversity of the plant resources and their indigenous knowledge of utilization (Kunwar and Bussmann 2008, Kunwar et al. 2008). In line with this, the present study was undertaken in Kanchanpur district in the far-western region of Nepal with objectives: i) to document the plant resources used by the local community, ii) to collect the information about the medicinal plant species, fodder species, fuel wood species, fruit and other miscellaneous use of plants, and iii) to identify the exploitation status of plant species for specific purposes.

\section{MATERIALS AND METHODS}

\section{Study area}

The study was conducted in Kanchanpur district $\left(28^{\circ} 32^{\prime}-29^{\circ} 8^{\prime} \mathrm{N}\right.$ and $\left.80^{\circ} 03^{\prime}-80^{\circ} 33^{\prime} \mathrm{E}\right)$ of Mahakali Zone of the Far-Western Development Region of Nepal. The elevation ranges from $160 \mathrm{~m}$ to $1528 \mathrm{~m}$ a.s.l. (The Siwalik Hills). The average annual rainfall of the district is $1775 \mathrm{~mm}$; the average maximum temperature is $43^{\circ} \mathrm{C}$ while the average minimum temperature is $3^{\circ} \mathrm{C}$. River systems, notably Mahakali river, Mohana river, Chaudhar river, etc. and several seasonal rivers impart a wide variation in climatic and micro climatic conditions and therefore, wide variety of forest types such as Sal forest, Terai Mixed Hard Wood Forest and Sissoo-Khair Forest (Operational Forest Management Plan, District Forest office 2010). The per capita agricultural land and population growth rate is 0.68 and 3.2, 
respectively. The economic opportunities of the people are livestock, farming NTFP's and their trade and vegetable cultivation (District Profile of Kanchanpur, District Development Committee 2010).

For collection of data on the use of plant resources, two Village Development Committees (VDCs), Daijee and Suda were selected that are situated at about $4 \mathrm{~km}$ and $10 \mathrm{~km}$, respectively, to the east of district headquarters, Mahendranagar. Suda VDC comprises of 2909 households with a total population of 18061 and Daijee VDC comprises of 3712 households with a total population of 11578 (CBS 2010). The study sites included community forests and government managed forests.

\section{Data collection}

Data generated from both primary and secondary sources were used in the study. The secondary sources include review of the literature i.e. journals, articles, books and published/unpublished documents. Most data were collected form primary sources. Field survey was conducted to document the ethnobotanical information about the plants. During that, field observation, group discussion, questionnaire survey and key informant surveys were used as major tools. Group discussions were held as informal interactions and they were organized within community forest user groups, traders, traditional healers (locally called Baidhya, Guruwa, Bharra). The key informants included senior person of the community, teachers and the local healers. A total of 325 respondents including 175 men and 150 women were asked for data collection that covered five wards of the VDCs. Finally the data were checked and verified using available literature sources and were presented in tabular as well as chart forms.

\section{Ranking of species based on socio-economic values}

The ranking exercise was carried out in each group discussion. Out of total listed species, local people were asked to select only 20 most valuable species in their respective area. The selection was based on the ethno-botanic perspective, i.e., ease of cultivation, market price and demand of the products, parts used, social acceptance for the cultivation and promotion, rate of collection, etc. The value varied from 20 for highly valuable species and 1 for the least valuable species.

\section{RESULTS}

The study area is rich in vegetation, the forest pasture and even the agriculture land support a greater number of plant species most of which have useful values. In present study, a total of 151 species of plant belonging to 58 families and 133 genera have been recorded including their detail information on use value. Among those, Leguminosae (12 species), Gramineae (12 species) and Moraceae (12 species) are the most dominant families followed by Euphorbiaceae ( 8 species), Liliaceae (6 species), Zingiberacece (4 species), Umbeliferae (4 species), Solanaceae (4 species), Labiatae (4 species), Cucurbitaceae (4 species), Combretaceae (3 species) and other families have 2 or one species. Of the total recorded plant species, the highest number, i.e., 69 species were used as medicinal followed by fodder ( 24 species) and fruits and vegetables (13, 12 species, respectively) (Fig. 1). Mostly used medicinal plants of the area are Acorus calamus, Rauvolfia serpentina, Piper longum, Asparagus racemosus, Terminalia bellirica, Withenia somnifera, Azadiracta indica, etc. On the other hand Trewia nudiflora, Morus alba, Ficus neriifolia and Ficus racemosa are specially used as fodder. Mostly used fruits are Erythrina arborescens, Annona 
squmata, Podophyllum hexandrum, Litchi chinensis, Carica papaya, Prunus persica, Ziziphus jujuba, Syzyzium cumuni, Aegle marmelos and Punica granatum. The vegetable species in the area include Bauhinia variagata, Colocasia esculenta, Dendrocalamus strictus, Atrocarpus heterophyllus, Chenopodium album and Rumex nepalensis.

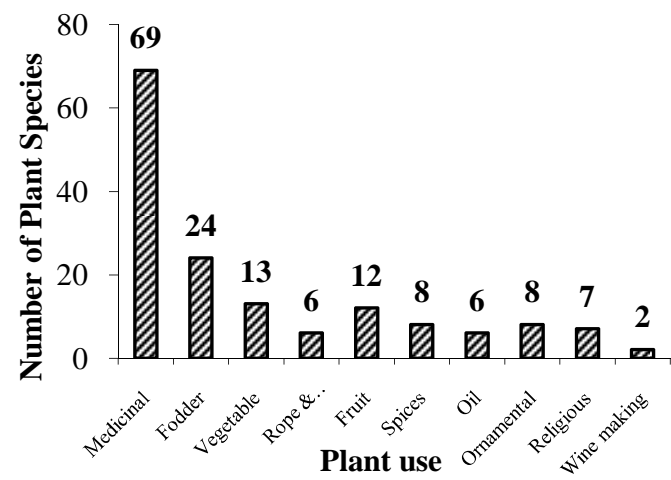

Fig. 1. Number of plant species according to their use.

Similarly, the plant species were grouped as herbs, shrubs, trees and climber with the highest proportion falling under herbs and shrubs (44\%, $40 \%$ ) respectively (Fig. 2)

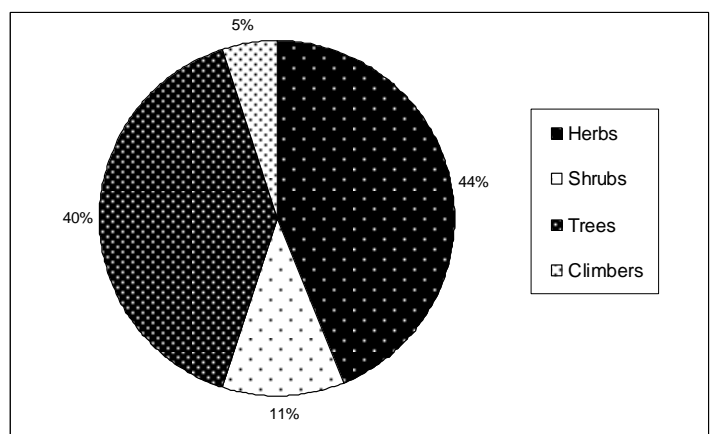

Fig. 2. Proportion of total plant species based on their major habits.
In terms of their parts used, the highest number of species were used for their leaf (63) followed by fruit (47), whole plant (31), root (32); and the least were resin (4), fibers (2) (Fig. 3)

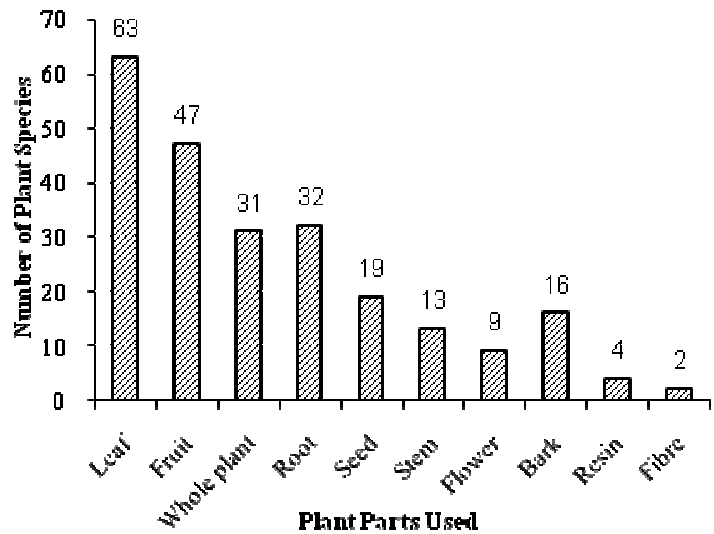

Fig. 3. Utilization pattern of different parts of plant species.

Out of total 151 species, 20 most exploited species were identified (Table 1). The most exploited species based on score include Asparagus racemosus, Acorus calamus, Rauvolfia serpentine, Piper longum, Emblica officinalis, Terminalia bellirica, etc. of the total sampled species, $12 \%$ are highly exploited while $61 \%$ are least exploited (Fig. 4).

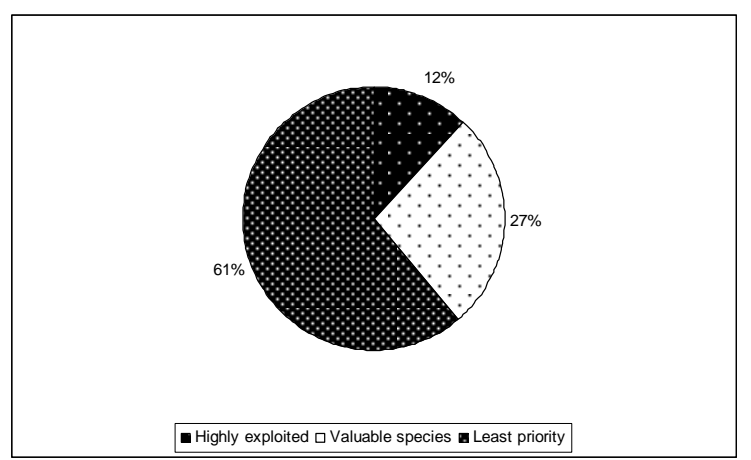

Fig. 4. Rate of exploitation of species.

ECOPRINT VOL 20, 2013 
Table 1. List of 20 most exploited plant species in the study area.

\begin{tabular}{cllcl}
\hline SN & Local Name & Scientific Name & Total Rank & Type of Product \\
\hline 1 & Kurilo & Asparagus racemosus & 135 & Tuber \\
2 & Bojho & Acorus calamus & 122 & Rhizome \\
3 & Sarphagandha & Rauvolfia serpentina & 120 & Roots \\
4 & Pipla & Piper longum & 115 & Dry fruit \\
5 & Amala & Emblica officinalis & 103 & Fruit pulp \\
6 & Barro & Terminallia bellirica & 100 & Fruit pulp \\
7 & Bel & Aegle marmelos & 94 & Fruit pulp \\
8 & Ashwagandha & Withenia somnifera & 82 & Root and Fruits \\
9 & Bamboo/Bans & Bambusa vulgaris & 76 & Whole plant \\
10 & Khair & Acacia catechu & 68 & Kattha \\
11 & Leamon grass & Cymbopogon citratus & 67 & Whole plant \\
12 & Bijaysal & Pterocarpus marsupium & 63 & Wooden glass \\
13 & Bhorla & Cordia vestita & 60 & Bark \\
14 & Muhroom & Morchella conica & 55 & Dry plant \\
15 & Rukh kathar & Atrocarpus heterophyllus & 48 & Fruit \\
16 & Sikakai & Cassia siamea & 46 & Whole plant \\
17 & Neem & Azadirchta indica & 42 & Leaf Bark and fruit \\
18 & Jhayu & Permellia nepalensis & 40 & Whole plant \\
19. & Harro & Terminallia chebula & 40 & fruit \\
\hline & & & & \\
\hline
\end{tabular}

\section{DISCUSSION}

Forest is the major natural resource for diverse ecosystem services for the people living particularly in the remote areas of the country. The people collect as much medicinal herbs and other products as anything and try to get the maximum amount of benefit. The records of the collection of plant resources, e.g. medicinal plants, in the last decades show that there is an increasing trend in the harvesting of the natural resource as a result of which most of the medicinal species are at the verge of extinction (Ghimire et al. 2005).

In present study a total of 154 species of plant belonging to 58 families and 133 genera have been recorded which are used as medicine, fodder, fruit, vegetable, raw material for making rope and basket, spices and other miscellaneous uses. Out of 69 medicinal plants documented here, 19 species have been described by Manandhar (1989) in his study of medicinal plants used by Chepang tribes of Makawanpur district. As many as 8 species seemed nearly similar in their use as reported there. Similarly, 9 species described in this study have also been described by Manandhar (1990) in his study of traditional phytotherapy of Danuwar tribes of Kamalakhong in Sindhuli district. Another 7 species are different in their uses. They were Jatropa curcas, Ricinus communis, Colebrookia oppositifolia, etc. In yet another study, as many as ten species recorded in present study has been reported with similar use in healing different ailments of human being in native phytotherapy of Raute tribes of Dadeldhura district (Manandhar 1998). Bhattarai (1992) has reported different medicinal uses of some plants reported here in his study of medical ethnobotany of Karnali zone. In a 
separate study, Kunwar and Bussmann (2008) have reported diversity, utilization and management of medicinal plants in Baitadi and Darchula districts. In these ecozones, the use of herbal resources is in contrast with their uses in other regions. This reflects diversity in ethnomedicinal knowledge of people in different regions.

Joshi and Joshi (2001) documented indigenous knowledge and use of medicinal plants by local communities in Kali Gandaki watershed area, Nepal and found some of the common plant species have different use. Cannabis sativa is used for thread making and seeds used in pickle making. Similarly, Chenopodium album is used for treating intestinal worms and as vegetable. Cymbopogon martinii is used for essential oil production and Jatropha curcas as antihelmintics.

Animal husbandry is one of the major occupations in the study area. Altogether 24 species are used as fodder. Of these, 7 species were good quality, 9 species were low quality and remaining 8 were satisfactory. Local people categorized fodder quality according to preference by their domestic cattle and subsequent rate of lactation. The low quality fodder species are fed at the time of fodder scarcity.

The local people mainly use Bauhinia variegata, Colocasia esculenta, Dendrocalamus strictus, Atrocarpus heterophyllus, Chenopodium album as vegetable. The species used for making rope and basket, and roofing are Agave americana, Eulaliopsis binata, Calamus latifolia, Saccharum spontaneum, Imperata cylindrica, Bambusa arundinacea, Cephalostachylum capitatum etc.They used Coriandrum sativum, Allium cepa, Zinziber officinalis, Piper longum, Curcuma domestica as spices. The major common fruit species are Litchi chinensis, Carica papaya, Syzizyum cumuni, Agele marmelos. The species used for religious purposes include Aegle marmelos, Oscimum sanctum, Ficus bengalensis,
Ficus religiosa, Saccharum spontaneum, etc. Concomitant with these, reports suggest that these wild plant species provide the local people with manifold valuable uses in the remote areas of mid hill regions of Nepal (Shrish et al. 2011a,b).

Although a total of 151 species have been documented from the studied Suda and Daijee VDCs of Kanchanpur district, not all the species are equally important in terms of local use value. Forty three species were identified as important and valuable for that area. Out of these species, only 20 species were selected as much valuable and much potential species for the promotion and further research and development. The northern and western belt of the study area were found to be more fertile for production of the etahnomedicinal species of high economic value such as Piper longum, Emblica officinalis, Asparagus racemosus, Terminellia chebula, Rauvolfia serpentina, Acacia catechu, Cinnamomum tamala, Withenia somnifera, etc. The highly valuable species for market value were found to be Asparagus racemosus, Rauvolfia serpentina, Acorus calamus among others. Owing to their higher use value and over exploitation, these are slowly and gradually leading towards extinction, so there is urgent need to conserve these species in their wilderness.

In conclusion, the far western region, Kanchanpur district area is rich in plant resources serving the local people in many ways and helping in sustaining livelihood. Most of the plant species are used as medicines while a large number of them are used as food and for other purposes. The local people are rich in their knowledge on traditional use and therefore, there is increase in exploitation, leading to threatening of some of the species of high use value. Owing to this, there is urgent need to take initiatives to conserve these resources. 


\section{ACKNOWLEDGEMENTS}

The first author is indebted to the local people, the DFO and school teachers of study area for their kind help and support during field work. Dr. M. Bhatta and Mr. D. Chand are acknowledged for their suggestions and support during the field work.

\section{REFERENCES}

Bhattarai, N.K. 1992. Medical ethanobotany in the Karnali zone, Nepal. Economic Botany 46(3):257-261.

CBS. 2010. Statistical Year Book of Nepal 2010. Central Bureau of Statistics, Kathmandu, Nepal.

District Forest Office, Kanchanpur. 2010. Operational Forest Management Plan. pp. 25 28.

District Development Committee (DDC). 2010. District Profile of Kanchanpur. Kanchanpur.

Ghimire, S.K., D. McKey and A.-T. Yildiz. 2005. Conservation of Himalayan medicinal plants: Harvesting patterns and ecology of two threatened species, Nardostachys grandiflora DC. and Neopicrorhiza scrophulariiflora (Pennell) Hong. Biological Conservation 124(4):463-475.

Joshi, K.K. and S.D. Joshi. 2001. Genetic Heritage of Medicinal and Aromatic Plants of Nepal Himalaya. Buddha Academic Publishers and Distributors Pvt. Ltd., Kathmandu, Nepal.

Joshi, A.R., S.L. Shrestha and K. Joshi. 2003. Environmental Management and Sustainable Development at the Crossroad. AnKus, Kathmandu, Nepal.

Kunwar, R.M. and R.W. Bussmann. 2008. Medicinal plants and quantitative ethno medicine: A case study from Baitadi and Darchula districts, far-west Nepal. Journal of Natural History Museum 24:72-81.

Kunwar, R.M., C. Burlakoti, C.L. Chaudhary and R.W. Bussmann.2008. Medicinal plants in farwest Nepal: Indigenous uses and pharmacological validity. Medicinal and Aromatic Plant Science and Biotechnology 4(1):28-42.
Manandhar, I.N. and T.H. Aase. 2003. Manang report (Translated from District Gazetteer, Nepal).

Manandhar, N.P. 1998. Native phytotherapy among the Raute tribe of Dadeldhura district, Nepal. Journal of Ethnopharmacology 60(2): 199-206.

Manandhar, N.P. 1989. Medicinal plants used by Chepang tribes of Makawanpur district, Nepal. Fitoterapia 60(1):61-68.

Manandhar, N.P. 1990. Traditional phytotherapy of Danuwar tribes of Kamlakhonj in Sindhuli district, Nepal. Fitoterapia 61(4):325-331.

NBS. 2002. Nepal Biodiversity Strategy. His Majesty's Government of Nepal, Ministry of Forest and Soil Conservation, Kathmandu, Nepal.

Pie Shengji, J. 2001. Ethanoecological approaches of traditional medicine studies: some experience from Asia. Pharmacoceutical Biology 39:74-79.

Shrestha, K.K. 1997. Ethnobotanical inventory and plant taxonomy: Basic approaches for ethnobotanical research. In: Ethnobotany for Conservation and Community Development. (eds.) Shrestha, K.K., P.K. Jha, P. Shengii, A. Rastogi, S. Rajbhandari and M. Joshi. pp. 5865.

Shrish, O., C.P. Pokhrel and R.K.P. Yadav. 2011a. Plant diversity in homegardens and their use value in two villages of Rupandehi District, Western Nepal. Ecoprint 18:85-90.

Shrish, O., C.P. Pokhrel and R.K.P. Yadav. 2011b. Food from the wild: Enhancing food security in Bharse VDC of Gulmi district, Western Nepal. Perspective on Higher Education Journal of TUTA University Campus 6:139145.

Yadav, R.K.P. 1999. Medicinal plants and traditional medical practice in eastern part of Parsa district, Nepal. Proceedings of the $3^{\text {rd }}$ National Conference on Science and Technology. RONAST, Kathmandu, pp. 14211426. 